\title{
Pengaruh Proporsi Tanaman terhadap Pertumbuhan dan Hasil Tumpangsari Kubis (Brassica oleracea Var. Capitata L.) dengan Tomat (Lycopersicum esculentum Mill.)
}

\author{
The Effect of Plant Proportion on Growth and Yield in Intercropping of \\ Cabbage (Brassica oleracea Var Capitata L.) with Tomato (Lycopersicum \\ esculentum Mill.)
}

\author{
Ariana Rusbiyati, Rohlan Rogomulyo *), Sri Muhartini \\ Departemen Budidaya Pertanian, Fakultas Pertanian, Universitas Gadjah Mada \\ *) Penulis untuk koresponden Email: rohlan_rm@yahoo.com
}

\begin{abstract}
The human population in Indonesia has increasing every year. It caused decreasing in agricultural land ownership due to high demand for residential land. In addition, it also affect the quantity of vegetable product to fulfill the needs of the community. Cabbage and tomatoes are vegetable commodities that have commercial value and high prospect. Intercropping is one of the agricultural intensification programs to increase yield and land productivity in one planting season. The regulation of the proportion of plants needs to be considered to obtain the optimal proportion of plants, so as to improve the efficient use of land and increase the production of both plants. This study entitled "The Effect of Plant Proportion on Growth and Yield in Intercropping of Cabbage (Brassica oleracea var Capitata L.) with Tomato (Lycopersicum esculentum Mill.)". The purpose of this study is to obtain a combination of the number of plants that provide favorable land productivity in cabbage and tomato intercropping systems. The research was conducted on June-September 2017 in paddy fields in Argomulyo, Cangkringan, Sleman, Daerah Istimewa Yogyakarta. The experiments were arranged in a single-group randomized complete block design (RCBD) with five treatments and three blocks as replicates. Factors tested were the ratio of the number of plants or the proportion of the population ie 100\% cabbage; $25 \%$ cabbage: $75 \%$ tomato; $50 \%$ cabbage: $50 \%$ tomato; $75 \%$ cabbage: $25 \%$ tomatoes; and $100 \%$ tomatoes. The results showed that intercropping with proportion of $75 \%$ cabbage and $25 \%$ tomato gave the best land productivity and favorable economic income because more than one land equivalency $(N K L<1)$ was 1.13 and economic value was IDR 76.773.870, -
\end{abstract}

Keywords : cabbage, tomato, intercropping, land equivalent ratio, growth

\section{INTISARI}

Jumlah penduduk di Indonesia mengalami peningkatan setiap tahunnya. Hal ini mengakibatkan penurunan luas kepemilikan lahan pertanian karena permintaan lahan pemukiman yang tinggi. Selain itu, juga akan berdampak terhadap kuantitas produksi sayuran untuk memenuhi kebutuhan masyarakat. Kubis dan tomat merupakan komoditas sayuran yang memiliki nilai komersial dan prospek yang tinggi. Tumpangsari 
merupakan salah satu program intensifikasi pertanian untuk meningkatkan hasil dan produktivitas lahan dalam satu musim tanam. Pengaturan proporsi tanaman perlu diperhatikan karena untuk mendapatkan proporsi tanaman yang optimal, sehingga dapat meningkatkan efisien penggunaan lahan dan meningkatkan produksi kedua tanaman. Penelitian ini berjudul "Pengaruh Proporsi Tanaman terhadap Pertumbuhan dan Hasil Tumpangsari Kubis (Brassica oleracea var. Capitata L.) dengan Tomat (Lycopersicum esculentum Mill.)". Tujuan penelitian ini adalah mendapatkan kombinasi perbandingan jumlah tanaman yang memberikan produktivitas lahan yang menguntungkan dalam sistem tumpangsari kubis dan tomat. Penelitian dilaksanakan pada Juni-September 2017 di lahan sawah di daerah Argomulyo, Cangkringan, Sleman, Daerah Istimewa Yogyakarta. Percobaan disusun dalam rancangan acak kelompok lengkap (RAKL) faktor tunggal dengan lima pelakuan dan tiga blok sebagai ulangan. Faktor yang diuji adalah perbandingan jumlah tanaman atau proporsi populasi yaitu $100 \%$ kubis; $25 \%$ kubis : $75 \%$ tomat; $50 \%$ kubis : $50 \%$ tomat; $75 \%$ kubis : $25 \%$ tomat; dan $100 \%$ tomat. Hasil penelitian menunjukkan tumpangsari dengan proporsi $75 \%$ kubis dan $25 \%$ tomat memberikan produktivitas lahan dan pendapatan ekonomi yang menguntungkan sebab nilai kesetaraan lahan lebih dari satu $(N K L<1)$, yaitu 1,13 dan nilai ekonomi sebesar Rp 76.773.870,--.

Kata kunci : kubis, tomat, tumpangsari, nisbah kesetaraan lahan, pertumbuhan

\section{PENDAHULUAN}

Permintaan sayuran sebagai bahan pelengkap makanan pokok akan terus berfluktuasi seiring dengan semakin bertambahnya jumlah penduduk. Pada tahun 2010, jumlah penduduk Indonesia yaitu sekitar 238 juta orang dan tahun 2015 mengalami peningkatan menjadi sekitar 255 juta orang (Anonim, 2016). Tingginya jumlah penduduk tersebut mengakibatkan permintaan akan lahan pemukiman pun semakin meningkat sehingga berdampak terhadap penurunan luas kepemilikan lahan pertanian atau biasa disebut dengan istilah alih fungsi lahan pertanian menjadi lahan non pertanian.

Kubis (Brassica oleracea) merupakan komoditas sayuran yang memiliki nilai komersial dan prospek yang tinggi. Untuk mencapai hasil optimal perlu dilakukan teknik budidaya yang tepat. Sebagian besar petani masih menggunakan sistem monokultur untuk meningkatkan produksi kubis. Sistem ini memiliki kelemahan, yaitu tanaman relatif mudah terserang hama maupun penyakit sehingga dapat menurunkan hasil panen. Tumpang sari merupakan salah satu bentuk dari program intensifikasi pertanian alternatif yang tepat untuk memperoleh hasil pertanian yang optimal (Prasetyo et al., 2009). Intensifikasi dengan cara ini dapat meningkatkan hasil per satuan luas lahan per satuan waktu, mengurangi resiko kegagalan panen, serta meningkatkan produktivitas lahan, tenaga, waktu, dan sumber usahatani yang tersedia selama satu musim tanam (Thahir dan Hatmadi, 1986 cit. Arinong, 2014). Tomat merupakan salah satu tanaman yang dapat digunakan dalam sistem tumpangsari tersebut. Tomat merupakan tanaman 
Ariana Rusbiyati et al., / Vegetalika. 2018. 7(4): 26-38

sayuran yang memiliki nilai ekonomi tinggi yang dapat digunakan sebagai sumber alternatif pendapatan petani (Cahyono, 2008 cit. Masfufah, 2012). Dengan demikian, hasil kubis dan tomat akan meningkat sehingga dapat memenuhi permintaan pasar. Selain itu juga ikut mendukung program pemerintah dalam rangka swasembada pangan.

Dalam budidaya tanaman secara tumpangsari akan terjadi interaksi seperti persaingan dalam hal ruang tumbuh, cahaya, air, dan unsur hara. Oleh karena itu proporsi tanaman dalam tumpangsari sangat penting untuk dilakukan. Pengaturan proporsi populasi bertujuan untuk mengatur tingkat kompetisi yang akan terjadi diantara tanaman dalam menggunakan sumberdaya. Pengaturan proporsi yang tidak ideal akan meningkatkan kompetisi antar tanaman menjadi lebih tinggi. Menurut Willey (1976) cit. Subrata (2016), bahwa sebenarnya sistem tumpangsari dapat menyebabkan penurunan hasil dari satu atau lebih tanaman komponen karena efek kompetisi, namun apabila pengaturan ruang dan tajuk tanaman dilakukan dengan baik justru akan meningkatkan hasil dari suatu atanaman tersebut.

Keuntungan secara agronomis dari pelaksanaan sistem tumpangsari dapat dievaluasi dengan menghitung nisbah kesetaraan lahan (NKL). Indeks NKL didapatkan dengan membandingkan pola tumpang sari dengan monokultur, NKL lebih besar $1(>1)$ berarti menguntungkan (Kidane et al., 1990; Kipkemori et al., 1997; Li et al., 2001; Suwarto et al., 2005; Ghulamahdi et al., 2007 cit. Aminah et al., 2013). Oleh karena itu perlunya dilakukan penelitian tentang penanaman tumpangsari kubis dan tomat untuk meningkatkan hasil dan pertumbuhan tanaman. Tujuan penelitian adalah mendapatkan kombinasi perbandingan jumlah tanaman yang memberikan produktivitas lahan yang menguntungkan dalam sistem tumpangsari kubis dengan tomat dan mendapatkan indeks tumpangsari yang mencakup nilai nisbah kesetaraan lahan (NKL), dan nilai ekonomi (NE) pada sistem tumpangsari kubis dengan tomat.

\section{BAHAN DAN METODE PENELITIAN}

Penelitian ini dilaksanakan pada bulan Juni - September 2017 di lahan sawah di daerah Argomulyo, Cangkringan, Sleman, Yogyakarta. Bahan yang digunakan dalam penelitian ini yaitu bibit kubis varietas Summer Autumn 633, bibit tomat varietas Servo, pupuk kandang sapi, pupuk kimia NPK dan pestisida kimia. Alat yang diperlukan yakni mulsa plastik, ajir tanaman, penggaris/meteran, tali raffia, karung, timbangan elektrik, gunting/cutter, oven, leaf area meter, jangka sorong, galat tulis, kamera, dan alat-alat pertanian diantaranya adalah cangkul, cetok, dan alat-alat bantu lainnya. 
Ariana Rusbiyati et al., / Vegetalika. 2018. 7(4): 26-38

Percobaan disusun dalam Rancangan Acak Kelompok Lengkap (RAKL) faktor tunggal dengan 5 perlakuan dan 3 blok sebagai ulangan. Faktor yang diuji adalah sistem tanam tumpangsari dengan rincian: T1 (Monokultur kubis 100\%); T2 (Kubis 25\% : Tomat 75\%); T3 (Kubis 50\% : Tomat 50\%); T4 (Kubis 75\% : Tomat 25\%); dan T5 (Monokultur tomat $100 \%)$. Jumlah tanaman kubis dan tomat terdiri dari masing-masing 56 tanaman (100\%), 14 tanaman (25\%), 28 tanaman (50\%), dan 42 tanaman (75\%). Tahap pelaksanaan penelitian terdiri atas persiapan bahan tanam, persiapan lahan, penanaman, pemeliharaan (pengairan, pengendalian gulma, pemupukan, pengendalian hama penyakit), dan panen.

Variabel penelitian yang diamati terdiri atas: tinggi tanaman, berat kering tajuk dan akar, hasil panen, laju pertumbuhan tanaman, laju asimilasi bersih, indeks luas daun, nilai kesetaraan lahan dan nilai ekonomi. Data yang diperoleh dari hasil pengamatan dianalisis dengan menggunakan analisis varian (ANOVA) dengan taraf $5 \%$. Apabila perlakuan menunjukkan perbedaan yang nyata dilanjutkan dengan uji beda nyata terkecil (BNT) LSD dengan taraf $5 \%$. Analisis data secara keseluruhan dikerjakan dengan menggunakan SAS.

\section{HASIL DAN PEMBAHASAN}

\section{Tinggi Tanaman}

Tinggi tanaman kubis dan tomat tidak menunjukkan perbedaan signifikan terhadap pola tumpangsari dan kepadatan populasi. Pertumbuhan tinggi tanaman kubis dan tomat baik yang ditumpangsari maupun monokultur relatif sama (Gambar 1). Hal ini diduga tanaman mampu memanfaatkan faktor tumbuh secara efisien dan beradaptasi pada setiap pola tanam. Prasetyo et al. (2009) menyatakan pertumbuhan tanaman tetap dapat berlangsung jika tanaman mampu memanfaatkan faktor tumbuh dan beradaptasi pada pola tanam yang ada.

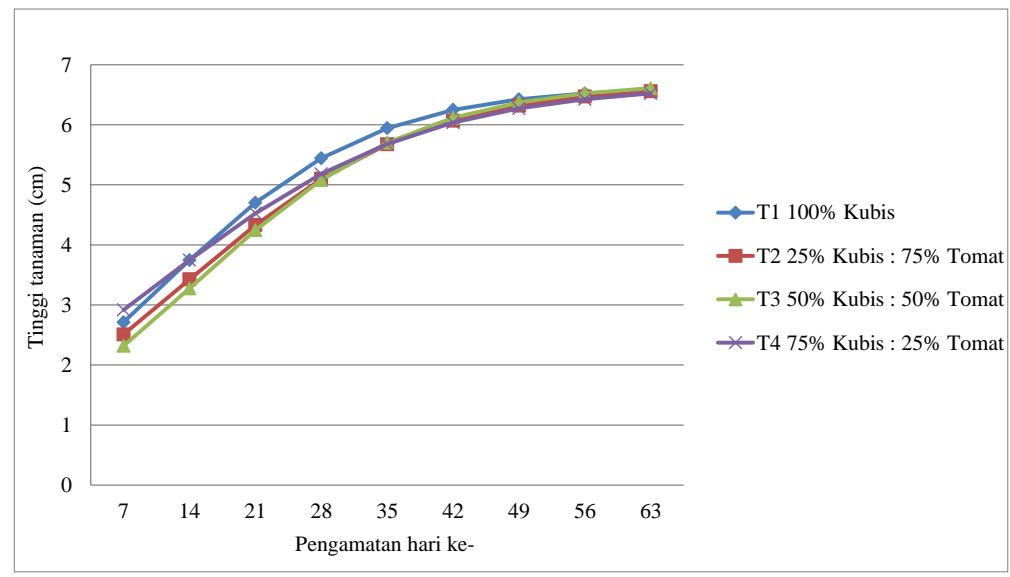


Ariana Rusbiyati et al., / Vegetalika. 2018. 7(4): 26-38

(a)

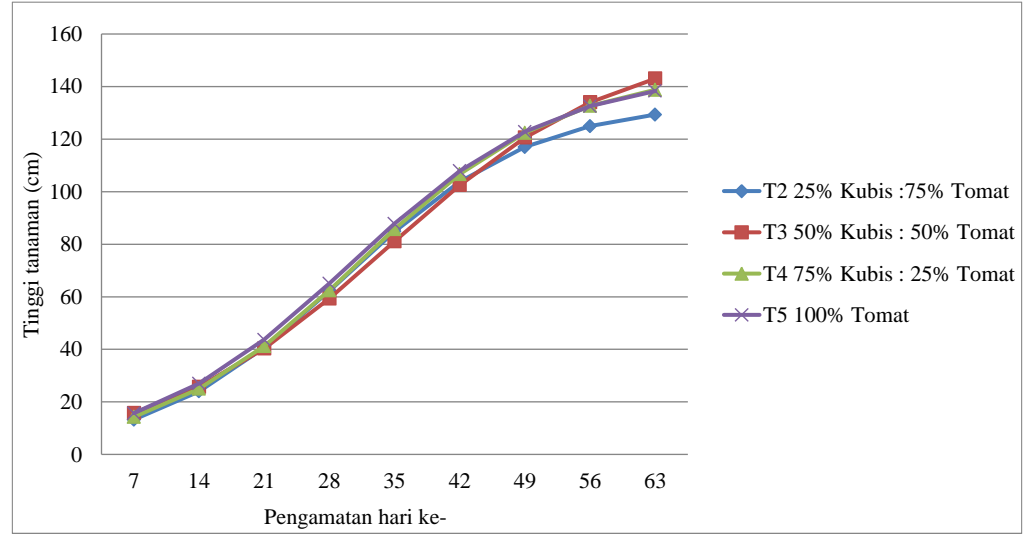

(b)

Gambar 1. Tinggi tanaman kubis (a) dan tomat (b) pada berbagai perlakuan (cm)

\section{Indeks Luas Daun}

Daun merupakan tempat berlangsungnya fotosintesis. Hasil fotosintesis tersebut akan dipergunakan tanaman untuk pertumbuhannya. Indeks luas daun merupakan salah satu peubah yang berperan dalam fotosintesis dan menentukan pertumbuhan dan perkembangan tanaman. Indeks luas daun menggambarkan kerapatan daun, maka apabila kerapatan daun tinggi akan memberikan pengaruh saling menaungi (Zakariyya, 2016).

Tabel 1. Rerata luas daun pada umur 3, 6, dan 9 mst.

\begin{tabular}{llll}
\hline \multirow{2}{*}{ Perlakuan } & \multicolumn{3}{c}{ Indeks Luas Daun } \\
\cline { 2 - 4 } & 3 MST & 6 MST & 9 MST \\
\hline Kubis & $0,21 \mathrm{a}$ & $2,74 \mathrm{a}$ & $4,28 \mathrm{a}$ \\
\hline T1 (100\% kubis) & $0,24 \mathrm{a}$ & $2,54 \mathrm{a}$ & $3,47 \mathrm{a}$ \\
T2 (25\% kubis : $75 \%$ tomat) & $0,24 \mathrm{a}$ & $2,82 \mathrm{a}$ & $3,31 \mathrm{a}$ \\
T3 (50\% kubis : $50 \%$ tomat) & $0,17 \mathrm{a}$ & $2,62 \mathrm{a}$ & $3,54 \mathrm{a}$ \\
T4 (75\% kubis : $25 \%$ tomat) & & & \\
\hline & $0,21 \mathrm{a}$ & $2,46 \mathrm{a}$ & $2,79 \mathrm{a}$
\end{tabular}




\begin{tabular}{lccc} 
T3 (50\% kubis : $50 \%$ tomat) & $0,17 \mathrm{a}$ & $3,09 \mathrm{a}$ & $3,52 \mathrm{a}$ \\
T4 (75\% kubis : $25 \%$ tomat) & $0,20 \mathrm{a}$ & $2,88 \mathrm{a}$ & $3,52 \mathrm{a}$ \\
T5 (100\% tomat) & $0,18 \mathrm{a}$ & $2,27 \mathrm{a}$ & $3,05 \mathrm{a}$ \\
\hline Keterangan : Angka yang diikuti dengan huruf yang sama pada kolom sama menunjukkan tidak \\
ada beda nyata berdasarkan uji lanjut beda nyata terkecil pada tingkat kepercayaan \\
95\%.
\end{tabular}

Berdasarkan hasil sidik ragam, proporsi populasi tidak berpengaruh nyata terhadap indeks luas daun kubis dan tomat saat berumur 3, 6, dan 9 MST (Tabel 1). Secara fisiologis semakin lama umur tanaman indeks luas daun tanaman akan semakin besar karena terjadi pertumbuhan. Cahaya yang diterima tanaman dengan indeks luas daun besar akan lebih banyak dibandingkan dengan tanaman yang memiliki luas indeks daun kecil (Perwitasari et al., 2012). Setter dan Flanigan (1985) cit. Myrna (2005) mengemukakan bahwa jika kondisi lingkungan dan tanaman baik, meningkatnya indeks luas daun sampai batas tertentu akan meningkatkan fotosintesis. Dengan meningkatnya nilai ILD, maka akan meningkatkan pula hasil bersih asimilasi. Seiring dengan meningkatnya laju asimilasi bersih maka akan meningkatkan pertumbuhan tanaman.

\section{Laju Asimilasi Bersih}

Laju asimilasi bersih merupakan indikator penumpukan bahan kering pada tanaman. Semakin tinggi laju asimilasi bersih semakin banyak penumpukan bahan kering (Buhaira, 2009). Laju asimilasi bersih berhubungan dengan indeks luas daun, daun yang menerima cahaya matahari lebih banyak mampu menghasilkan fotosintat yang tinggi dibandingkan dengan daun yang kurang atau terlindung cahaya matahari. Semakin banyak daun yang menerima cahaya matahari maka semakin tinggi laju asimilasi bersih.

Tabel 2. Rerata laju asimilasi bersih (g/cm2/minggu) pada umur 3-9 mst.

\begin{tabular}{|c|c|c|}
\hline \multirow{2}{*}{ Perlakuan } & \multicolumn{2}{|c|}{ Laju Asimilasi Bersih ( $\left.\mathrm{g} / \mathrm{cm}^{2} / \mathrm{minggu}\right)$} \\
\hline & 3-6 MST & 6-9 MST \\
\hline \multicolumn{3}{|l|}{ Kubis } \\
\hline T1 (100\% kubis) & $0,00679 a$ & $0,00125 \mathrm{a}$ \\
\hline T2 (25\% kubis : $75 \%$ tomat) & $0,00748 \mathrm{a}$ & $0,00055 \mathrm{a}$ \\
\hline T3 (50\% kubis : $50 \%$ tomat) & $0,00716 \mathrm{a}$ & $0,00043 \mathrm{a}$ \\
\hline T4 (75\% kubis : $25 \%$ tomat) & $0,00954 \mathrm{a}$ & $0,00178 \mathrm{a}$ \\
\hline \multicolumn{3}{|l|}{ Tomat } \\
\hline T2 (25\% kubis :75\% tomat) & $0,00730 \mathrm{~b}$ & $0,00183 \mathrm{a}$ \\
\hline T3 (50\% kubis : $50 \%$ tomat) & 0,00833 a & $0,00191 \mathrm{a}$ \\
\hline
\end{tabular}



T4 (75\% kubis : $25 \%$ tomat) $\quad 0,00797 \mathrm{ab} \quad 0,00179 \mathrm{a}$

T5 (100\% tomat) $\quad 0,00710 \mathrm{~b} \quad 0,00189 \mathrm{a}$
Keterangan : Angka yang diikuti dengan huruf yang sama pada kolom sama menunjukkan tidak ada beda nyata berdasarkan uji lanjut beda nyata terkecil pada tingkat kepercayaan $95 \%$.

Berdasarkan hasil sidik ragam, proporsi populasi tidak berpengaruh nyata terhadap laju asimilasi bersih sampai tanaman kubis berumur 9 MST (Tabel 2) sehingga proses fotosintesis relatif sama antar perlakuan. Laju asimilasi bersih tanaman tomat hanya menunjukkan perbedaan saat umur 6-9 MST (Tabel 2). Secara garis besar, saat umur 3-6 MST tanaman memiliki laju asimilasi bersih lebih tinggi dibandingkan saat tanaman berumur 6-9 MST. Hal tersebut sesuai pernyataan Subrata (2016), nilai laju asimilasi bersih akan menurun dengan semakin bertambahnya umur tanaman karena semakin meningkatnya indeks luas daun semakin banyak yang ternaungi.

\section{Laju Pertumbuhan Tanaman}

Indeks luas daun dan laju asimilasi bersih akan berpengaruh terhadapa laju pertanaman tanaman. Nilai indeks luas daun dan laju asimilasi bersih yang tinggi akan meningkatkan laju pertumbuhan tanaman. Laju pertumbuhan tanaman adalah variabel yang menggambarkan kemampuan tanaman menghasilkan bahan kering hasil asimilasi tiap satuan luas lahan tiap satuan waktu (Setyowati, 2013).

Tabel 3. Rerata laju pertumbuhan tanaman pada umur 3-9 mst (g/ $\left.\mathrm{cm}^{2} / \mathrm{minggu}\right)$.

\begin{tabular}{|c|c|c|}
\hline \multirow{2}{*}{ Perlakuan } & \multicolumn{2}{|c|}{ Laju Pertumbuhan Tanaman } \\
\hline & 3-6 MST & 6-9 MST \\
\hline \multicolumn{3}{|l|}{ Kubis } \\
\hline T1 (100\% kubis) & $0,00663 \mathrm{a}$ & $0,00420 \mathrm{a}$ \\
\hline T2 (25\% kubis : $75 \%$ tomat) & $0,00690 \mathrm{a}$ & $0,00171 \mathrm{a}$ \\
\hline T3 (50\% kubis : $50 \%$ tomat) & $0,00718 \mathrm{a}$ & $0,00134 \mathrm{a}$ \\
\hline T4 (75\% kubis : $25 \%$ tomat) & $0,00729 \mathrm{a}$ & $0,00321 \mathrm{a}$ \\
\hline \multicolumn{3}{|l|}{ Tomat } \\
\hline T2 (25\% kubis : $75 \%$ tomat) & $0,00617 \mathrm{ab}$ & $0,00460 \mathrm{a}$ \\
\hline T3 (50\% kubis : $50 \%$ tomat) & $0,00803 \mathrm{a}$ & $0,00550 \mathrm{a}$ \\
\hline
\end{tabular}


T4 (75\% kubis : $25 \%$ tomat)

$0,00776 \mathrm{ab}$

0,00548 a

T5 (100\% tomat)

$0,00546 \mathrm{~b}$

0,00465 a

Keterangan : Angka yang diikuti dengan huruf yang sama pada kolom sama menunjukkan tidak ada beda nyata berdasarkan uji lanjut beda nyata terkecil pada tingkat kepercayaan $95 \%$.

Berdasarkan hasil sidik ragam, proporsi populasi tidak berpengaruh nyata terhadap laju pertumbuhan tanaman kubis (Tabel 3 ) sehingga proses fotosintesis relatif sama antar perlakuan. Laju pertumbuhan tanaman tomat hanya menunjukkan perbedaan saat umur 6-9 MST (Tabel 3). Menurut Alom et al. (2010) cit. Subrata (2016) penurunan proporsi populasi dalam tumpangsari akan menurunkan laju pertumbuhan tersebut karena terjadi kompetisi dalam memperebutkan unsur hara dan cahaya antar komponen tanaman penyusun dalam tumpangsari. Laju pertumbuhan tanaman akan menurun dengan bertambahnya umur tanaman. Proporsi populasi mempengaruhi laju pertumbuhan tanaman. Semakin banyak populasi tanaman laju pertumbuhan semakin rendah dan sebaliknya. Hal ini dikarenakan terjadi persaingan antar tanaman dalam pemanfaatan faktor tumbuh.

\section{Berat Kering Tajuk dan Berat Kering Akar}

Peningkatan berat kering tanaman menunjukkan bahwa tanaman mengalami pertumbuhan (Guritno dan Sitompul, 1995 cit. Rahayu et al., 2006). Peningkatan kerapatan populasi tanaman akan meningkatkan produksi bahan kering tanaman, sampai suatu maksimum, yaitu pada saat peningkatan kerapatan populasi tanaman lebih lanjut tidak diikuti lagi oleh peningkatan produksi bahan kering tanaman (Donald, 1963).

Tabel 4. Rerata berat kering tajuk (g) pada umur 3, 6, dan 9 mst.

\begin{tabular}{|c|c|c|c|}
\hline \multirow{2}{*}{ Perlakuan } & \multicolumn{3}{|c|}{ Berat Kering Tajuk (g) } \\
\hline & $3 \mathrm{MST}$ & $6 \mathrm{MST}$ & $9 \mathrm{MST}$ \\
\hline \multicolumn{4}{|l|}{ Kubis } \\
\hline T1 (100\% kubis) & $2,57 a b$ & 45,15 a & $70,11 \mathrm{a}$ \\
\hline T2 (25\% kubis : $75 \%$ tomat) & $2,81 \mathrm{a}$ & $46,94 \mathrm{a}$ & $56,28 \mathrm{~b}$ \\
\hline T3 (50\% kubis : $50 \%$ tomat) & $2,68 a$ & $48,87 \mathrm{a}$ & $55,55 \mathrm{~b}$ \\
\hline T4 (75\% kubis : $25 \%$ tomat) & $1,81 \mathrm{~b}$ & $48,70 \mathrm{a}$ & $67,00 \mathrm{ab}$ \\
\hline \multicolumn{4}{|l|}{ Tomat } \\
\hline T2 (25\% kubis : $75 \%$ tomat) & $2,86 a$ & $42,28 a b$ & $72,65 a b$ \\
\hline T3 (50\% kubis : $50 \%$ tomat) & $2,48 a$ & $54,08 \mathrm{a}$ & $91,03 \mathrm{a}$ \\
\hline T4 (75\% kubis : $25 \%$ tomat) & $2,41 a$ & $52,11 \mathrm{a}$ & $88,73 a b$ \\
\hline
\end{tabular}


T5 (100\% tomat)

2,46 a

$37,12 \mathrm{~b}$

$68,11 \mathrm{~b}$

Keterangan : Angka yang diikuti dengan huruf yang sama pada kolom sama menunjukkan tidak ada beda nyata berdasarkan uji lanjut beda nyata terkecil pada tingkat kepercayaan $95 \%$.

Tabel 5. Rerata berat kering akar (g) pada umur 3, 6, dan 9 mst.

\begin{tabular}{|c|c|c|c|}
\hline \multirow{2}{*}{ Perlakuan } & \multicolumn{3}{|c|}{ Berat Kering Akar (g) } \\
\hline & $3 \mathrm{MST}$ & $6 \mathrm{MST}$ & $9 \mathrm{MST}$ \\
\hline \multicolumn{4}{|l|}{ Kubis } \\
\hline T1 (100\% kubis) & $0,16 b$ & $2,33 \mathrm{a}$ & $5,68 \mathrm{a}$ \\
\hline T2 (25\% kubis : $75 \%$ tomat) & $0,17 \mathrm{ab}$ & $2,60 \mathrm{a}$ & $4,79 \mathrm{a}$ \\
\hline T3 (50\% kubis : $50 \%$ tomat) & $0,22 \mathrm{a}$ & $2,51 \mathrm{a}$ & $4,84 \mathrm{a}$ \\
\hline T4 (75\% kubis : $25 \%$ tomat) & $0,14 b$ & $2,45 \mathrm{a}$ & $5,81 \mathrm{a}$ \\
\hline \multicolumn{4}{|l|}{ Tomat } \\
\hline T2 (25\% kubis : $75 \%$ tomat) & $0,32 \mathrm{a}$ & $2,54 \mathrm{a}$ & $3,19 a b$ \\
\hline T3 (50\% kubis : $50 \%$ tomat) & $0,23 a$ & $2,80 \mathrm{a}$ & $2,97 a b$ \\
\hline T4 (75\% kubis : $25 \%$ tomat) & $0,28 a$ & $2,95 a$ & $3,30 \mathrm{a}$ \\
\hline T5 (100\% tomat) & $0,24 \mathrm{a}$ & $2,40 \mathrm{a}$ & $2,79 \mathrm{~b}$ \\
\hline \multicolumn{4}{|c|}{$\begin{array}{l}\text { Keterangan : Angka yang diikuti dengan huruf yang sama pada kolom sama menunjukkan tid } \\
\text { ada beda nyata berdasarkan uji lanjut beda nyata terkecil pada tingkat kepercayac } \\
95 \% \text {. }\end{array}$} \\
\hline \multicolumn{4}{|c|}{ Hasil analisis pada tabel 4 dan tabel 5 menunjukkan bahwa ada perbedaa } \\
\hline \multicolumn{4}{|c|}{ signifikan antara berat kering tajuk maupun akar dalam pertumbuhan tanaman. hal } \\
\hline \multirow{2}{*}{\multicolumn{4}{|c|}{$\begin{array}{l}\text { berarti proporsi populasi tanaman tidak mempengaruhi pertumbuhan tajuk dan akar } \\
\text { masing-masing tanaman. Hal ini dikarenakan tidak terjadi persaingan ketat dalam } \\
\text { penggunaan air, cahaya dan unsur hara yang tersedia. Berat kering tanaman merupakan }\end{array}$}} \\
\hline & & & \\
\hline \multirow{2}{*}{\multicolumn{4}{|c|}{$\begin{array}{l}\text { hasil penimbunan asimilat oleh tanaman. Berat kering tanaman meningkat dengan } \\
\text { bertambahnya umur tanaman. Hal ini berarti asimilat dimanfaatkan dan didistribusikan }\end{array}$}} \\
\hline & & & \\
\hline ebagai nutrisi kes & & & \\
\hline
\end{tabular}

\section{Berat Segar dan Berat Kering Krop Kubis}

Berat krop per tanaman sangat dipengaruhi oleh laju fotosintesis. Proses fotosintesis sangat mempengaruhi hasil fotosintat. Apabila ketersediaan air, unsur hara atau cahaya matahri berkurang, maka akan mepengaruhi laju fotosintesis yang kemudian akan mengakibatkan menurunnya produksi suatu tanaman (Gardner et al., 1991). Pada umur 3 MST belum ada krop yang terbentuk atau krop belum terbentuk secara sempurna dan saat umur 6 MST krop kubis belum terbentuk sempurna. Pada umur 9 MST, perlakuan T1 (100\% kubis) dan T4 (75\% kubis : $25 \%$ tomat) memiliki berat 
Ariana Rusbiyati et al., / Vegetalika. 2018. 7(4): 26-38

segar dan kering krop kubis lebih tinggi dibandingkan perlakuan lainnnya (Tabel 4.4.2). Hal ini menunjukkan bahwa berat segar dan berat kering meningkat dengan tingginya proporsi populasi kubis.

Tabel 6. Berat segar krop dan kering krop kubis.

\begin{tabular}{lcc}
\hline \multicolumn{1}{c}{ Perlakuan } & $\begin{array}{c}\text { Berat Segar Krop }(\mathrm{kg}) \\
(9 \mathrm{MST})\end{array}$ & $\begin{array}{c}\text { Berat Kering Krop }(\mathrm{g}) \\
(9 \mathrm{MST})\end{array}$ \\
\hline T1 (100\% kubis) & $1,17 \mathrm{a}$ & $65,82 \mathrm{a}$ \\
T2 (25\% kubis : $75 \%$ tomat) & $0,80 \mathrm{~b}$ & $46,82 \mathrm{~b}$ \\
T3 (50\% kubis : $50 \%$ tomat) & $0,80 \mathrm{~b}$ & $46,59 \mathrm{~b}$ \\
T4 (75\% kubis : $25 \%$ tomat) & $1,21 \mathrm{a}$ & $60,02 \mathrm{a}$
\end{tabular}

Keterangan : Angka yang diikuti dengan huruf yang sama pada kolom sama menunjukkan tidak ada beda nyata berdasarkan uji lanjut beda nyata terkecil pada tingkat kepercayaan $95 \%$.

\section{Berat Buah Tomat per Tanaman}

Berat buah per tanaman menunjukkan potensi hasil dari tanaman tersebut. Berat buah tomat semakin meningkat dengan bertambahnya umur tanaman. Hal ini menunjukkan bahwa hasil fotosintesis ditranskolasikan ke bagian buah. Proporsi populasi tanaman tidak memberikan pengaruh nyata terhadap berat buah per tanaman. Hal ini diduga tanaman masih dapat memanfaatan faktor tumbuh dengan baik. Berdasarkan hasil analisis sidik ragam, proporsi populasi tidak berpengaruh nyata terhadap berat buah per tanaman saat tanaman berumur 3 MST, 6 MST, dan 9 MST (Tabel 7).

Tabel 7. Rerata berat segar buah pada umur 3, 6, dan $9 \mathrm{mst}$ (kg/tanaman).

\begin{tabular}{lccc}
\hline \multirow{2}{*}{ Perlakuan } & \multicolumn{3}{c}{ Berat Segar Buah $(\mathrm{kg})$} \\
\cline { 2 - 4 } & $3 \mathrm{MST}$ & $6 \mathrm{MST}$ & $9 \mathrm{MST}$ \\
\hline T2 (25\% kubis $:$ 75\% tomat) & $0,00 \mathrm{a}$ & $0,13 \mathrm{a}$ & $1,66 \mathrm{a}$ \\
T3 (50\% kubis : $50 \%$ tomat) & $0,00 \mathrm{a}$ & $0,15 \mathrm{a}$ & $2,07 \mathrm{a}$ \\
T4 (75\% kubis : $25 \%$ tomat) & $0,00 \mathrm{a}$ & $0,19 \mathrm{a}$ & $2,13 \mathrm{a}$ \\
T5 (100\% tomat) & $0,00 \mathrm{a}$ & $0,10 \mathrm{a}$ & $1,60 \mathrm{a}$
\end{tabular}

Keterangan : Angka yang diikuti dengan huruf yang sama pada kolom sama menunjukkan tidak ada beda nyata berdasarkan uji lanjut beda nyata terkecil pada tingkat kepercayaan 95\%. Angka 0 (nol) pada umur 3 MST menunjukkan buah belum terbentuk.

\section{Hasil Panen, Nisbah Kesetaraan Lahan dan Nilai Ekonomi}


Ariana Rusbiyati et al., / Vegetalika. 2018. 7(4): 26-38

Untuk melihat apakah tanaman yang ditumpangsari menguntungkan atau tidak dapat dianalisis dengan pendekatan indeks tumpangsari. Nisbah kesetaraan lahan (NKL) digunakan untuk menghitung keuntungan secara agronomis dalam sistem tumpangsari, nilai NKL >1 berarti tumpangsari menguntungkan (Rifai et al., 2014). Nilai ekonomi (NE) digunakan untuk untuk menghitung keuntungan secara ekonomis dalam sistem tumpangsari. Nilai ekonomi merupakan perhitungan pendapatan yang dihasilkan dari berat panen yang dijual dihitung dari hasil penerimaan kotor yang dihitung dengan mengalikan produksi tanaman dengan harga pada saat panen (Subrata, 2016).

Hasil panen kubis dan tomat dipengaruhi oleh proporsi populasi tanaman, semakin tinggi populasi tanaman maka hasil panen juga semakin meningkat (Tabel 8). Nisbah kesetaraan lahan paling tinggi dalam penelitian ini adalah perlakuan T4 $(75 \%$ kubis : $25 \%$ tomat) dengan NKL sebesar 1,13 (Tabel 8). Hal ini berarti tumpangsari menguntungkan secara agronomis karena dimungkinkan perlakuan tersebut merupakan kepadatan optimal yang mampu menciptakan iklim mikro yang baik untuk produksi tanaman. Tomat dengan proporsi $25 \%$ tidak memberikan naungan terhadap kubis $75 \%$, sehingga kedua tanaman tersebut mampu memanfaatkan cahaya, air, dan unsur hara dengan baik. Nilai ekonomi komoditas dalam penelitian ini masih dibawah monokultur tomat meskipun lebih tinggi dari monokultur kubis (Tabel 8). Perlakuan T4 (75\% kubis : $25 \%$ tomat) memiliki pendapatan yang dikira mampu memberikan keuntungan bagi petani.

Tabel 8. Hasil panen, nisbah kesetaraan lahan, dan nilai ekonomi berbagai perlakuan.

\begin{tabular}{|c|c|c|c|c|}
\hline \multirow{2}{*}{ Perlakuan } & \multicolumn{2}{|c|}{ Hasil Panen (ton/ha) } & \multirow{2}{*}{ NKL } & \multirow{2}{*}{$\begin{array}{l}\text { Nilai Ekonomi } \\
(\mathrm{Rp})\end{array}$} \\
\hline & Kubis & Tomat & & \\
\hline T1 (100\% kubis) & $25,54 \mathrm{a}$ & - & - & $\operatorname{Rp} 63.857 .410$ \\
\hline T2 (25\% kubis : $75 \%$ tomat) & $4,40 d$ & $27,18 b$ & 0,95 & Rp 74.327.137 \\
\hline T3 (50\% kubis : $50 \%$ tomat) & $8,73 \mathrm{c}$ & $22,65 b$ & 0,98 & $\operatorname{Rp} 74.596 .031$ \\
\hline T4 (75\% kubis : $25 \%$ tomat) & $19,83 \mathrm{~b}$ & $11,67 d$ & 1,13 & Rp 76.773.870 \\
\hline T5 (100\% tomat) & - & $34,98 \mathrm{a}$ & - & Rp 81.496.887 \\
\hline
\end{tabular}

\section{KESIMPULAN}


1. Secara agronomis, nilai nisbah kesetaraan lahan (NKL) tumpangsari dengan proporsi $25 \%$ kubis : $75 \%$ tomat sebesar 0,95 ; proporsi $50 \%$ kubis : $50 \%$ tomat sebesar 0,98; dan proporsi $75 \%$ kubis : $25 \%$ tomat sebesar 1,13 . Secara ekonomis, nilai ekonomi (NE) tumpangsari dengan proporsi $25 \%$ kubis : $75 \%$ tomat sebesar Rp 74.327.137,-; proporsi 50\% kubis : 50\% tomat sebesar Rp 74.596.031,-; dan proporsi $75 \%$ kubis : $25 \%$ tomat sebesar Rp 76.773.870,.

2. Penanaman sistem tumpangsari dengan proporsi $75 \%$ kubis : $25 \%$ tomat dalam penelitian ini memberikan produktivitas lahan dan pendapatan ekonomi yang menguntungkan sebab nisbah kesetaraan lahan lebih dari satu $(\mathrm{NKL}<1)$ dan pendapatan ekonomi lebih tinggi dari monokultur kubis dan lebih rendah dari monokultur tomat.

\section{SARAN}

Perlu adanya penelitian lebih lanjut mengenai budidaya kubis dan tomat secara tumpangsari dengan perlakuan proporsi tanaman yang berbeda dari penelitian sebelumnya.

\section{DAFTAR PUSTAKA}

Aminah, I. S., D. Budianta, Y. Parto, Munandar, dan Erizal. 2013. Tumpangsari Kedelai-Jagung, Jarak Tanam, dan Pupuk Hayati di Lahan Pasang Surut. Seminar Hasil Penelitian Tanaman Aneka Kacang dan Umbi. Prosiding.

Anonim. 2016. Badan Pusat Statistik : Proyeksi Penduduk menurut Provinsi, 2010-2035 (Ribuan). <https://www.bps.go.id/linkTabelStatis/view/id/1274>. Diakses pada 10 Desember 2016.

Arinong, A.R. 2014. Meningkatkan Produktivitas Lahan dengan Pertanian Ramah Lingkungan. < http://www.stppgowa.ac.id/informasi/artikel-ilmiah/252meningkatkan-produktivitas-lahan-dengan-pertanian-ramah-lingkungan.html . Diakses pada 10 Mei 2018.

Donald, C. M. 1963. Competition among Crop and Pasture Plant. Adv. Agron15 Hal : 1-118.

Gardner, F.P., R.B. Pearce, Roger L. Mitchell. 1991. Fisiologi Tanaman Budidaya. Penerjemah Herawati Susilo dan Pendamping Subiyanto. Cetakan pertama. Universitas Indonesia. Jakarta.

Masfufah, A. 2012. Pengaruh pemberian pupuk hayati (biofertilizer) pada berbagai dosis pupuk dan media tanam yang berbeda terhadap pertumbuhan dan produktivitas tanaman tomat (Lycopersicon esculentum). Fakultas Sains dan Teknologi, Universitas Airlangga. Skripsi. 
Myrna, N. E. F. 2005. Pemupukan N pada jagung pada ultisol dengan sistem olah tanah minimum. Jurnal Agronomi Vol. 10 No. 1, Hal : 9-25.

Perwitasari, B., M. Tripatmasari, dan C. Wasonowati. 2012. Pengaruh media tanam dan nutrisi terhadap pertumbuhan dan hasil tanaman pakchoi (Brassica juncea L.) dengan sistem hidroponik. Agrovigor 5 : 14-25.

Prasetyo, E. I. Sukardjo dan H. Pujiwati. 2009. Produktivitas lahan dan nkl pada tumpang sari jarak pagar dengan tanaman pangan. Jurnal Akta Agrosia $12: 51-55$.

Rahayu, M., D. Prajitno, dan A. Syukur. 2006. Pertumbuhan vegetatif padi gogo dan beberapa varietas nanas dalam sistem tumpangsari di lahan kering Gunung Kidul, Yogyakarta. Biodiversitas. Vol. 7, No. 1 Hal : 73-76.

Rifai, A., S. Basuki, dan B. Utomo. 2014. Nilai kesetaraan lahan budi daya tumpang sari tanaman tebu dengan kedelai: studi kasus di Desa Karangharjo, Kecamatan Sulang, Kabupaten Rembang. Widyariset, Vol. 17, No.1, Hal : 59-70.

Setyowati, M. L., E. Sulistyaningsih, dan E. T. S. Putra. 2013. Pertumbuhan dan hasil kubis (Brassica oleraceae L.) dalam sistem tumpangsari dengan bawang daun (Allium fistulosum L.). Vegetalika Vol.2, No.3, Hal : 32-44.

Subrata, A. G. 2016. Pengaruh proporsi populasi padi gogo dan kacang hijau dalam tumpangsari terhadap hasil dan komposisi gulma di lahan pasir pantai. Fakultas Pertanian Universitas Gadjah Mada, Yogyakarta. Tesis.

Zakariyya, F. 2016. Menimbang Indeks Luas Daun Sebagai Variabel Penting Pertumbuhan Tanaman Kakao. Warta Pusat Penelitian Kopi dan Kakao Indonesia. 